\title{
Pemanfaatan casa dalam observasi motilitas spermatozoa semen cair Sapi Madura dalam pengencer berbeda
}

\author{
Dian Ratnawati ${ }^{1}$, Nurul Isnaini ${ }^{2}$ dan Trinil Susilawati ${ }^{2}$ \\ ${ }^{1}$ Loka Penelitian Sapi Potong, Grati Pasuruan, Indonesia \\ ${ }^{2}$ Fakultas Peternakan, Universitas Brawijaya Malang, Indonesia
}

Correspondence author: dian_sapo@yahoo.co.id dan trinil_susilawati@yahoo.com

\begin{abstract}
The purpose of this study was to measure the motility of Madura bull spermatozoa using three different diluents (tris aminomethane, CEP-2 and skim milk) during cold storage. The research material used were 2 Madura bulls. Collecting semen method used artificial vagina, followed by fresh semen analysis and processing of liquid semen. Observation of liquid semen quality was carried out up to the 5th days of cold storage. Motility examination of semen liquid used Computerized Assisted Semen Analysis (CASA), namely SCA v.5.2. The parameters measured were: progressive motility, motility, velocity straight linear (VSL), velocity curve linear (VCL), velocity average pathway (VAP), straightness (STR), linearity (LIN), wobble (WOB), hyperactivity $(\mathrm{H})$, Beat cross frequency $(\mathrm{BCF})$, amplitude lateral head (ALH). Data was analyzed by Minitab 17. Motility and progressive motility of spermatozoa in tris aminomethane and CEP-2 were higher than skim milk for 5 days of cold storage. The VCL value of tris aminomethane was higher than CEP-2 and skim milk. VSL scores barely show the difference among diluents. VAP values in tris aminomethaneand CEP-2 are higher than skim milk at the beginning of storage. The LIN, STR and WOB values of the CEP-2 and skim milk yield higher values than tris aminomethane. The percentage value of hyperactivity spermatozoa was same among diluents. The ALH value of trisaminomethane was higher than CEP-2 and skim milk. BCF values in CEP-2 was higher than skim milk and tris aminomethane. Tris aminomethane and CEP-2 can support the motility of Madura bull spermatozoa than skim milkfor 5 days of storage.
\end{abstract}

Keywords: motility, Madura bull, CASA

PENDAHULUAN

Sapi Madura merupakan salah satu plasma nutfah sapi potong di Indonesia yang layak dilestarikan. Keberlangsungan populasi sapi Madura harus tetap terjaga agar tidak terjadi kepunahan. Salah satu upaya untuk mendukung program pembibitan berupa seleksi, dapat dilakukan dengan penyebaran pejantan pemacek maupun semen beku untuk wilayah yang kekurangan pejantan (Kutsiyah, 2012).

Seiring dalam perkembangannya, terdapat beberapa kelemahan semen beku diantaranya tidak dapat mempertahankan kualitas semen selama proses pembekuan. Semen cair menawarkan berbagai kelebihan diantaranya: sarana dan prasarana yang lebih sederhana; efisien dan mampu mempertahankan kualitas spermatozoa selama penyimpanan \pm 10 hari (Vishwanath and Shannon, 2000).

Terdapat banyak faktor yang mempengaruhi keberhasilan semen cair, salah satu diantaranya adalah pengencer. Beberapa fungsi dari pengencer diantaranya: menambah 
volume semen, buffer/penyangga, sumber nutrisi, mencegah cold chock, mengandung antibiotika (anti bakteri), menciptakan lingkungan yang kondusif, dan sebagai krioprotektan (Kostaman dan Sutama, 2006). Beberapa pengencer yang sudah banyak digunakan adalah tris aminomethanee, CEP-2 dan susu skim. Setiap pengencer mempunyai kekurangan dan kelemahan dalam pemanfaatannya.

Tris aminomethane merupakan pengencer yang sudah banyak digunakan sebelumnya dan mempunyai performan yang baik dalam mendukung kualitas spermatozoa (Yohana et al., 2014; Wiratri et al., 2014; Tambing et al., 2009). Sedangkan CEP-2 mempunyai keunggulan diantaranya adalah mengandung komposisi ion dan osmolaritas yang menyerupai komposisi ion cairan plasma di epididimis sehingga dapat mendukung kualitas spermatozoa, motilitas dan integritas membran spermatozoa (Ducha et al., 2012; Indriani et al., 2013; Purwoistri et al., 2013). Susu skim merupakan salah satu bahan yang dapat digunakan sebagai pengencer semen dalam prosesing semen cair. Susu merupakan cairan penyangga (buffer) yang bersifat alami, namun mempunyai efek yang lebih rendah dari asam sitrat (Arifiantini et al., 2013). Keunggulan susu skim diantaranya mampu mendukung kualitas semen tetap baik, ketersediaan mudah dan ekonomis (Akhter et al., 2010). Pengencer susu skim mampu mendukung motilitas setelah thawing lebih optimal dibandingkan dengan pengencer lainnya.

Analisis kualitas semen cair selama penyimpanan dilakukan untuk mengetahui status kelayakan semen cair. Parameter motilitas, viabilitas dan integritas membran biasanya digunakan untuk menentukan kualitas semen cair selama penyimpanan. Motilitas spermatozoa dapat diukur secara visual maupun menggunakan CASA. Hasil penilaian motilitas dengan CASA lebih obyektif, akurat, repeatable dan terstandar. Standar penilaian CASA berdasarkan pola gerakan dan lintasan (trajectory) spermatozoa. (Simonik et al., 2015; Didion, 2008; Amann and Waberski, 2014; Lange-Consiglio et al., 2013; Sarastina, 2006).

Tujuan penelitian ini adalah menganalisa motilitas spermatozoa semen cair Sapi Madura dengan menggunakan pengencer berbeda selama simpan dingin.

\section{MATERI DAN METODE}

\section{Materi penelitian}

Penelitian menggunakan 2 ekor sapi jantan Madura umur 4-5 tahun. Lokasi penelitian adalah kandang percobaan dan Laboratorium Reproduksi Ternak Lolit Sapi Potong (Grati, Pasuruan). Durasi penelitian 2 bulan, mulai bulan Desember 2016Januari 2017.

\section{Metode penelitian}

Sapi jantan ditampung sebanyak 5 kali untuk menghasilkan 10 ulangan. Penampungan dilakukan pada pagi hari pukul 06:00-07:00 WIB, dengan menggunakan vagina buatan. Hanya semen dengan kualitas baik yang diproses menjadi semen cair. Pembuatan semen cair diawali dengan perhitungan konsentrasi spermatozoa dalam semen segar untuk selanjutnya dijadikan dasar perhitungaan jumlah pengencer yang dibutuhkan. Rumus yang digunakan dalam pengenceran ini adalah:

$$
\mathrm{V}_{1} \mathrm{M}_{1}=\mathrm{V}_{2} \mathrm{M}_{2},
$$

Keterangan

$\mathrm{V}_{1}$ : volume semen segar 
$\mathrm{M}_{1}$ : konsentrasi semen segar

$\mathrm{V}_{2}$ : volume semen cair (semen segar + pengencer

$\mathrm{M}_{2}$ : konsentrasi semen cair (100 juta/ml)

Target konsentrasi spermatozoa pada semen cair adalah $100 \mathrm{juta} / \mathrm{ml}$. Semen cair ditempatkan pada tabung reaksi kaca, ditutup dengan plastic wrap dan diletakkan dalam backer glass tanpa water jacket. Penyimpanan semen cair dalam refrigerator suhu $3-5^{\circ} \mathrm{C}$ dan dilakukan observasi secara berkala.

Setiap semen segar yang layak diproses menjadi semen cair dicampur dalam tiga pengencer berbeda. Terdapat tiga pengencer yang digunakan dalam penelitian ini yaitu tris aminomethanee, CEP-2 dan susu skim. Komposisi tiga pengencer yang digunakan dalam penelitian ini tertera pada Tabel 1 .

Tabel 1. Komposisi Pengencer Semen Cair.

Pengencer

Komposisi bahan dalam pengencer

Pengencer I (Tris Aminomethane) tris aminomethane 1,262 g; asam sitrat 0,762 g; laktosa $1,500 \mathrm{~g}$; fruktosa $0,500 \mathrm{~g}$; kuning telur 20\%; streptomycin 0,100 g; aquadest $80 \mathrm{ml}$ dan penicillin $0,100 \mathrm{~g}$.

Pengencer II (CEP-2)

Pengencer III (Susu skim)
$\mathrm{KCl} 7 \mathrm{mmol} / \mathrm{L}, \mathrm{NaCl} 15 \mathrm{mmol} / \mathrm{L}, \mathrm{MgCl}_{2}\left(\mathrm{H}_{2} \mathrm{O}\right)_{6}$ $4 \mathrm{mmol} / \mathrm{L}, \mathrm{CaCl}_{2}\left(\mathrm{H}_{2} \mathrm{O}\right)_{2} 3 \mathrm{mmol} / \mathrm{L}, \mathrm{NaHCO}_{3}$ $11,9 \mathrm{mmol} / \mathrm{L}, \mathrm{NaH}_{2} \mathrm{PO}_{4} 8 \mathrm{mmol} / \mathrm{L}, \mathrm{KH}_{2} \mathrm{PO}_{4} 20$ $\mathrm{mmol} / \mathrm{L}$, Sorbitol $1 \mathrm{~g} / \mathrm{L}$, Fruktosa $55 \mathrm{mmol} / \mathrm{L}$, Tris $133,7 \mathrm{mmol} / \mathrm{L}$, gentamicin-S $0,05 \mathrm{~g} / \mathrm{L}$, asam sitrat $42 \mathrm{mmol} / \mathrm{L}$, kuning telur $10 \%$ dan putih telur $0,4 \%$.

susu skim, glukosa, aquades steril, antibiotik (penisilin dan streptomisin), kuning telur $10 \%$.
Pengamatan kualitas semen cair (parameter motilitas spermatozoa) dilakukan selama 5 hari menggunakan sistem CASA yaitu Sperm Class Analyzer (SCA) v. 5.2. Microptic, Barcelona, Spanyol. Standar frame rate (FR) yang digunakan CASA adalah 25 fps (frame per second).

\section{Analisis kualitas semen segar}

Pengukuran $\mathrm{pH}$ semen dilakukan dengan menggunakan $\mathrm{pH}$ indikator (Susilawati, 2011). Penilaian warna dan konsistensi secara subyektif dengan menggerakkan semen pada tabung berskala (Susilawati, 2011). Penilaian volume semen menggunakan tabung berskala (Susilawati, 2011). Penilaian motilitas secara subyektif oleh 2-3 analis. Penilaian gerak masa menggunakan mikroskop perbesaran 10 $\mathrm{X} 10$, standar penilaian mengacu pada (Susilawati, 2011). Perhitungan konsentrasi dengan menggunakan haemocytometer (Hafez, 2008; Ax et al, 2008). Total sperma motil (TSM) dihitung dengan mengalikan volume $\mathrm{x}$ motilitas $\mathrm{x}$ konsentrasi dalam satuan $\mathrm{juta} / \mathrm{ml}$.

\section{Analisis motilitas spermatozoa dengan CASA}

Analisis diawali dengan mengambil sampel semen cair sebanyak 3-4 $\mu \mathrm{l}$, diletakkan dalam object glass suhu $37^{\circ} \mathrm{C}$ dan tutup dengan cover 
glass. Mikroskop diposisikan pada perbesaran 10 x 10 dan fase kontras pH1. Dilakukan pemasangan green filter pada cermin reflektor dan diatur cahaya serta diafragma, disesuaikan dengan standar warna pada layar komputer (Anonimous, 2016). Pengambilan gambar spermatozoa pada layar monitor sebanyak 5 gambar (field). Hasil analisa berupa nilai ratarata ataupun nilai setiap gambar tersaji dalam file excel.

\section{Analisis viabilitas dan abnormalitas}

Pemeriksaan viabilitas dan abnormalitas semen segar diawali dengan membuat smear semen menggunakan object glass. Dilakukan pencampuran 1 tetes semen dengan 1 tetes pewarna eosin negrosin kemudian dicampur dengan ose, diulas dan difiksasi dengan api. Pemeriksaan smear semen dengan menggunakan mikroskop perbesaran $1000 \mathrm{x}$. Dilakukan evaluasi sebanyak 100 spermatozoa, spermatozoa mati akan berwarna merah sedangkan spermatozoa hidup berwarna transparan. Identifikasi normal dan abnormalitas spermatozoa sampai dengan 100 spermatozoa. Jenis abnormalitas mengacu pada Hafez (2008). Nilai yang didapatkan, dibagi dengan jumlah total spermatozoa yang diamati (hidup dan mati atau normal dan tidak normal) dan dikalikan $100 \%$ (Ax et al., 2008) sehingga didapatkan persentasi viabilitas dan abnormalitas spermatozoa.

\section{Parameter penelitian dan analisis data}

Parameter yang diukur dalam studi ini diantaranya adalah warna, $\mathrm{pH}$, konsistensi, konsentrasi, volume, gerak masa, viabilitas, abnormalitas spermatozoa dan total spermatozoa motil pada semen segar. Parameter semen cair yang diukur menggunakan SCA v. 5.2. diantaranya adalah: motilitas progresif, motilitas, hiperaktif, VSL, VCL, VAP, LIN, STR, BCF, WOB dan ALH.

Rancangan penelitian menggunakan RAL (Rancangan Acak Lengkap) pola searah. Data disajikan dalam bentuk file excel dan dianalisa menggunakan Minitab 17.

\section{HASIL DAN PEMBAHASAN}

\section{Kualitas semen segar}

Hasil penampungan semen sapi jantan Madura selama kegiatan penelitian dan kualitas semen segar sapi Madura tertera pada Tabel 2.

Tabel 2. menunjukkan bahwa

\begin{tabular}{|c|c|c|}
\hline No & Parameter Kualitas Semen Segar & Hasil Analisa \\
\hline 1 & Volume (ml) & $5,7 \pm 0,5$ \\
\hline 2 & PH & $6,6 \pm 0,5$ \\
\hline 3 & Warna & Krem bening \\
\hline 4 & Konsistensi & Sedang-kental \\
\hline 5 & Konsentrasi (juta/ml) & $1076,0 \pm 127,6$ \\
\hline 6 & Gerak Massa & $2,0 \pm 0,0$ \\
\hline 7 & Viabilitas (\%) & $85,0 \pm 5,3$ \\
\hline 8 & Motilitas progresif (\%) & $66,0 \pm 6,5$ \\
\hline 9 & Total Spermatozoa Motil (juta) & $4020,9 \pm 758,9$ \\
\hline 10 & Abnormalitas (\%) & $4,4 \pm 1,8$ \\
\hline
\end{tabular}

kualitas semen segar sapi Madura baik dan layak diproses menjadi semen cair. 
Motilitas 66\% sudah memenuhi kriteria kualitas semen standar sapi jantan menurut Ax et al. (2008) yaitu 50\%. Motilitas semen segar $70 \%$ layak diproses menjadi semen cair dan semen beku. Total spermatozoa motil (TSM) mencapai 4020,9 juta.

Konsentrasi spermatozoa di atas $1000 \mathrm{juta} / \mathrm{ml}$ menunjukkan semen telah memenuhi standar semen sapi jantan (200-1800 juta/ml). Nilai viabilitas $85,0 \%$ dan abnormalitas spermatozoa 4,4\% sudah memenuhi standar kualitas semen sapi jantan menurut Ax et al. (2008) yaitu $80 \%$ dan $<20 \%$.

Abnormalitas yang ditemukan dalam semen sapi Madura diantaranya: kepala

Tabel 3. Motilitas dan motilitas progresif spermatozoa semen cair Sapi Madura selama simpan dingin.

\begin{tabular}{|c|c|c|c|c|c|c|c|c|c|c|}
\hline \multirow{3}{*}{$\begin{array}{c}\text { Parameter } \\
\text { Motilitas (\%) }\end{array}$} & \multirow{3}{*}{$\begin{array}{c}\begin{array}{c}\text { Hari } \\
\text { ke- }(\mathrm{H})\end{array} \\
0\end{array}$} & \multicolumn{9}{|c|}{ Pengencer } \\
\hline & & \multicolumn{3}{|c|}{$\begin{array}{c}\text { Tris } \\
\text { Aminomethane }\end{array}$} & \multicolumn{3}{|c|}{ CEP-2 } & \multicolumn{3}{|c|}{ Susu skim } \\
\hline & & 93,6 & \pm & 2,4 & 92,3 & \pm & 2,1 & 91,0 & \pm & 4,5 \\
\hline & 1 & 87,6 & \pm & 3,6 & 88,6 & \pm & 3,9 & 84,5 & \pm & 5,3 \\
\hline & 2 & 85,6 & \pm & 4,3 & 83,5 & \pm & 9,9 & 81,6 & \pm & 5,3 \\
\hline & 3 & 84,4 & \pm & $3,6^{\mathrm{a}}$ & 78,6 & \pm & $7,3^{\mathrm{ab}}$ & 70,7 & \pm & $6,6^{\mathrm{b}}$ \\
\hline & 4 & 84,5 & \pm & $3,7^{\mathrm{a}}$ & 81,1 & \pm & $4,9^{\mathrm{a}}$ & 65,7 & \pm & $8,6^{\mathrm{b}}$ \\
\hline & 5 & 80,4 & \pm & $7,5^{\mathrm{a}}$ & 75,3 & \pm & $12,2^{\mathrm{ab}}$ & 61,2 & \pm & $13,0^{\mathrm{b}}$ \\
\hline \multirow{6}{*}{$\begin{array}{c}\text { Mot Progresif } \\
(\%)\end{array}$} & 0 & 84,3 & \pm & $2,2^{\mathrm{a}}$ & 84,6 & \pm & $3,2^{\mathrm{a}}$ & 75,6 & \pm & $2,4^{\mathrm{b}}$ \\
\hline & 1 & 79,3 & \pm & $8,1^{\mathrm{a}}$ & 77,8 & \pm & $7,4^{\mathrm{a}}$ & 63,5 & \pm & $12,6^{\mathrm{b}}$ \\
\hline & 2 & 76,0 & \pm & $5,5^{\mathrm{a}}$ & 67,8 & \pm & $11,5^{\mathrm{ab}}$ & 61,6 & \pm & $5,0^{\mathrm{b}}$ \\
\hline & 3 & 68,8 & \pm & $5,0^{\mathrm{a}}$ & 58,3 & \pm & $13,7^{\mathrm{ab}}$ & 50,8 & \pm & $9,5^{\mathrm{b}}$ \\
\hline & 4 & 64,4 & \pm & $8,5^{\mathrm{a}}$ & 56,6 & \pm & $3,6^{\mathrm{ab}}$ & 42,5 & \pm & $9,8^{\mathrm{b}}$ \\
\hline & 5 & 59,8 & \pm & $7,9^{\mathrm{a}}$ & 51,1 & \pm & $10,4^{\mathrm{ab}}$ & 37,0 & \pm & $4,6^{\mathrm{b}}$ \\
\hline
\end{tabular}

Keterangan: superskrip yang berbeda pada baris yang sama menunjukkan perbedaan yang signifikan $(\mathrm{P}<0,05)$.

Berdasarkan Tabel 3. diketahui bahwa motilitas spermatozoa pada awal penyimpanan tidak menunjukkan perbedaan nyata. Namun pada spermatozoa saja (decapitated head sperms), kepala spermatozoa kecil (microchepalus sperms), kepala bentuk buah pear (pear shape sperms), spermatozoa ekor melingkar (coiled tail sperms) dan kepala spermatozoa ganda (double head sperms).

Motilitas spermatozoa semen cair Sapi Madura dengan tiga pengencer berbeda.

\section{Motilitas dan motilitas progresif}

Hasil pengamatan motilitas dan motilitas progresif spermatozoa semen cair sapi Madura selama penyimpanan dingin tertera pada Tabel 3 . 
susu skim $(70,7 \% ; 61,2 \%)$, namun tidak berbeda nyata dengan CEP-2 (78,6\%; $75,3 \%$ ). Pada H4 motilitas spermatozoa dalam pengencer tris aminomethane $(84,5 \%)$ dan CEP-2 $(81,1 \%)$ lebih tinggi secara nyata daripada pengencer susu $\operatorname{skim}(65,7 \%)$.

Nilai motilitas progresif spermatozoa antar pengencer menunjukkan perbedaan nyata selama penyimpanan dingin. Pada $\mathrm{H} 0$ dan $\mathrm{H} 1$ motilitas progresif pada pengencer tris aminomethane $(84,3 \%$; 9,3\%) dan CEP$2(84,6 \% ; 77,8 \%)$ lebih tinggi secara nyata $(\mathrm{P}<0,05)$ daripada pengencer susu skim $(75,6 \% ; 63,5 \%)$. Sedangkan pada $\mathrm{H} 2-\mathrm{H} 5$ motilitas progresif spermatozoa dalam pengencer tris aminomethane berbeda nyata $(\mathrm{P}<0,05)$ lebih tinggi $(76,0 \% ; \quad 68,8 \% ; \quad 64,4 \% ; \quad 59,8 \%)$ daripada pengencer susu skim $(61,6 \%$; $50,8 \%$; 42,5\%; 37,0\%), namun tidak berbeda nyata dengan pengencer CEP-2 $(6,8 \% ; 58,3 \% ; 56,6 \% ; 51,1 \%)$.

Penilaian motilitas dan motilitas progresif spermatozoa menggunakan SCA 5.2. mengacu pada standar WHO. Persentasi motilitas spermatozoa merupakan persentasi spermatozoa yang mempunyai VAP $<25 \mu \mathrm{m} / \mathrm{s}$. Sedangkan persentasi motilitas progresif spermatozoa merupakan persentasi spermatozoa dengan nilai VAP >25 $\mu \mathrm{m} / \mathrm{s}$ (Contri et al., 2010). Hasil penelitian lain menyatakan bahwa kriteria spermatozoa motil progresif apabila kecepatan gerak $>20 \mu \mathrm{m} / \mathrm{s}$ dan spermatozoa motil apabila kecepatan gerak $>5 \mu \mathrm{m} / \mathrm{s}$ (Massanyi et al, 2008). Nilai motilitas, motilitas progresif dan integritas membran berperan penting dalam mendukung fertilitas sapi jantan (Abavisani et al., 2013). Membran yang intact (utuh) berfungsi dalam membangun ikatan dengan zona pellucida. Kemampuan spermatozoa menembus cumulus dan zona pellucida membutuhkan motilitas spermatozoa yang baik (Ducha et al., 2014; Singh et al., 2011).

Selama masa simpan terdapat penurunan motilitas dan motilitas progresif spermatozoa secara bertahap. Derajat penurunan motilitas dan motilitas progresif pada pengencer tris aminomethane lebih rendah daripada CEP-2 dan susu skim. Pengencer tris aminomethane dan CEP-2 dapat mempertahankan motilitas dan motilitas progresif spermatozoa selama masa simpan. Pada H5, motilitas progresif spermatozoa dalam pengencer tris aminomethan dan CEP-2 adalah 59,8\% dan $51,1 \%$. Hasil penelitian Lukman et al (2014) menyatakan bahwa motilitas semen cair pada sapi Bali pada hari ke-5 mencapai $55,3 \%$. Penurunan motilitas $(61,2 \%)$ dan motilitas progresif $(37,0 \%)$ spermatozoa dalam pengencer susu skim lebih tinggi (drastis) selama simpan dingin.

Penurunan motilitas disebabkan adanya pengurasan sumber energi selama penyimpanan dingin. Hal ini diduga karena sumber energi dalam susu skim yang terbatas yaitu glukosa. Sedangkan pada pengencer tris aminomethane dan CEP-2 sumber energi meliputi laktosa dan fruktosa (tris aminomethane) serta fruktosa dan sorbitol (CEP-2). Energi yang digunakan untuk bergerak berasal dari siklus krebs, transfer elektron phosporilasi oksidatif dalam bentuk ATP dan AMP yang berfungsi mengubah fruktosa menjadi asam laktat dan $\mathrm{CO}_{2}$. Komposisi lain yang berpengaruh dalam pengencer terhadap motilitas spermatozoa adalah adanya buffer/ penyangga. Tris dan sitrat dalam pengencer tris aminomethane dan CEP2 berfungsi dalam mempertahankan $\mathrm{PH}$ tetap stabil (tidak turun) sehingga motilitas spermatozoa terjaga (Widjaya, 2011). Komponen tersebut tidak terdapat dalam pengencer susu skim 
sehingga $\mathrm{pH}$ lebih cepat turun dan penurunan motilitas dalam pengencer susu skim lebih besar. Lama simpan dan media pengencer mempengaruhi motilitas spermatozoa (Zaenuri et al., 2012). Selama penyimpanan, metabolisme spermatozoa tetap berjalan dengan menghasilkan hasil samping diantaranya asam laktat. Akumulasi asam laktat selama simpan dingin dapat mempengaruhi motilitas spermatozoa (Widjaya, 2011). Tardif et al. (1997) menyatakan media susu skim menghasilkan pengencer dengan kekentalan lebih tinggi sehingga mempengaruhi pergerakan spermatozoa. Kondisi yang berbeda pada pengencer tris aminomethane dan CEP-2, dimana pengencer mempunyai kekentalan lebih rendah sehingga memungkinkan spermatozoa bergerak lebih aktif dan tidak terbatasi.

Pada semua media pengencer terdapat penambahan kuning telur sebanyak 10\% (CEP-2) dan 20\% (tris aminomethane dan susu skim). Selain itu, dalam pengencer CEP-2 juga ditambahkan putih telur $0,4 \%$ sebagai pengganti BSA. Meskipun dalam preparasinya pengencer sudah disentrifuse, namun tidak menutup kemungkinan debris masih dapat mengganggu penilaian spermatozoa. Susu dan telur (albumin dan egg yolk) merupakan produk biologi. Masalah utama pada pengencer berbahan dasar susu dan kuning telur adalah merupakan produk biologi yang terdiri dari beberapa komponen yang tidak dapat distandarisasi dan bersifat variatif. Penggunaan produk biologi tersebut memungkinkan adanya partikel dan debris yang berada diantara spermatozoa sehingga teridentifikasi sebagai static sperm. Tingginya static sperm dapat membiaskan penilaian karena dapat menurunkan penilaian motilitas terhadap spermatozoa. Kualitas spermatozoa yang sesungguhnya mungkin lebih baik daripada hasil yang tertampil di CASA.

Beberapa komponen produk biologi memberikan efek yang menguntungkan, namun komponen lainnya dapat memberikan efek yang merugikan terhadap fungsi spermatozoa. Konsentrasi spermatozoa yang terlalu tinggi pada pengencer memberikan efek yang merugikan pada motilitas spermatozoa. Konsentrasi yang tinggi membatasi ruang gerak spermatozoa sehingga lintasan spermatozoa yang sesungguhnya tidak dapat tertangkap oleh CASA (SCA). Faktor yang lain adalah tingginya peluang antar kepala spermatozoa saling kolisi (menempel) sehingga pergerakan spermatozoa terhambat.

\section{VCL, VAP, VSL}

Nilai velocity (VCL, VSL dan VAP) semen cair sapi Madura selama penyimpanan dingin tertera pada Tabel 4. 
Tabel 4. VCL, VSL dan VAP spermatozoa semen cair Sapi Madura selama simpan dingin.

\begin{tabular}{|c|c|c|c|c|c|c|c|c|c|c|}
\hline \multirow{4}{*}{$\begin{array}{c}\text { Parameter } \\
\text { VCL } \\
(\mu \mathrm{m} / \mathrm{s})\end{array}$} & \multirow{3}{*}{$\begin{array}{c}\text { Hari } \\
\text { ke- } \\
(\mathrm{H})\end{array}$} & \multicolumn{9}{|c|}{ Pengencer } \\
\hline & & \multicolumn{3}{|c|}{$\begin{array}{c}\text { Tris } \\
\text { Aminomethane }\end{array}$} & \multicolumn{3}{|c|}{ CEP-2 } & \multicolumn{3}{|c|}{ Susu skim } \\
\hline & & 53,3 & \pm & $6,2^{\mathrm{ab}}$ & 59,6 & \pm & $8,2^{\mathrm{a}}$ & 46,1 & \pm & $2,4^{b}$ \\
\hline & 1 & 60,5 & \pm & $9,0^{\mathrm{a}}$ & 52,3 & \pm & $8,3^{\mathrm{b}}$ & 43,3 & \pm & $4,6^{c}$ \\
\hline & 2 & 61,5 & \pm & $9,8^{\mathrm{a}}$ & 48,2 & \pm & $10,8^{\mathrm{b}}$ & 41,9 & \pm & $4,7^{b}$ \\
\hline & 3 & 54,4 & \pm & $6,3^{\mathrm{a}}$ & 40,4 & \pm & $9,7^{\mathrm{b}}$ & 37,8 & \pm & $6,8^{b}$ \\
\hline & 4 & 52,0 & \pm & $4,8^{\mathrm{a}}$ & 38,8 & \pm & $5,6^{\mathrm{b}}$ & 35,3 & \pm & $5,9^{\mathrm{b}}$ \\
\hline & 5 & 54,3 & \pm & 8,1 & 45,1 & \pm & 7,2 & 41,9 & \pm & 9,0 \\
\hline VSL & 0 & 30,1 & \pm & 2,4 & 32,1 & \pm & 4,6 & 28,1 & \pm & 3,7 \\
\hline$(\mu \mathrm{m} / \mathrm{s})$ & 1 & 22,8 & \pm & $4,5^{\mathrm{ab}}$ & 27,0 & \pm & $5,0^{\mathrm{a}}$ & 20,2 & \pm & $4,7^{b}$ \\
\hline & 2 & 21,6 & \pm & 3,7 & 25,6 & \pm & 6,8 & 20,6 & \pm & 1,5 \\
\hline & 3 & 18,2 & \pm & 3,4 & 22,8 & \pm & 6,6 & 19,1 & \pm & 2,9 \\
\hline & 4 & 17,6 & \pm & 3,4 & 20,9 & \pm & 3,8 & 16,8 & \pm & 2,6 \\
\hline & 5 & 17,8 & \pm & 3,9 & 23,0 & \pm & 3,5 & 22,2 & \pm & 4,4 \\
\hline VAP & 0 & 36,4 & \pm & $3,7^{\mathrm{ab}}$ & 41,7 & \pm & $6,0^{\mathrm{a}}$ & 34,0 & \pm & $2,8^{b}$ \\
\hline$(\mu \mathrm{m} / \mathrm{s})$ & 1 & 32,6 & \pm & $6,9^{\mathrm{a}}$ & 33,1 & \pm & $6,5^{\mathrm{a}}$ & 25,5 & \pm & $4,4^{\mathrm{b}}$ \\
\hline & 2 & 32,7 & \pm & $5,1^{\mathrm{a}}$ & 31,4 & \pm & $8,6^{\mathrm{ab}}$ & 26,0 & \pm & $1,4^{b}$ \\
\hline & 3 & 28,7 & \pm & 5,3 & 26,8 & \pm & 7,1 & 23,8 & \pm & 4,2 \\
\hline & 4 & 26,8 & \pm & 3,7 & 24,8 & \pm & 4,2 & 21,9 & \pm & 2,7 \\
\hline & 5 & 27,5 & \pm & 4,8 & 29,2 & \pm & 4,0 & 27,8 & \pm & 6,3 \\
\hline
\end{tabular}

Keterangan: superskrip yang berbeda pada baris yang sama menunjukkan perbedaan yang signifikan $(\mathrm{P}<0,05)$.

Nilai VCL semen cair sapi Madura selama masa simpan menunjukkan perbedaan yang nyata $(\mathrm{P}<0,05)$ antar pengencer pada $\mathrm{H} 0-\mathrm{H} 4$. Pada H0 nilai VCL dalam pengencer CEP-2 lebih tinggi $(59,6 \mu \mathrm{m} / \mathrm{s})$ secara nyata $(\mathrm{P}<0,05)$ daripada susu skim $(46,1$ $\mu \mathrm{m} / \mathrm{s}$ ) dan tidak berbeda nyata dengan tris aminomethane $(53,3 \mu \mathrm{m} / \mathrm{s})$. Pada $\mathrm{H} 1$ nilai VCL dalam pengencer tris aminomethane yang lebih tinggi (60,5 $\mu \mathrm{m} / \mathrm{s})$ secara nyata $(\mathrm{P}<0,05)$ daripada CEP-2 $(52,3 \mu \mathrm{m} / \mathrm{s})$ dan susu skim $(43,3$ $\mu \mathrm{m} / \mathrm{s})$. Pada $\mathrm{H} 2-\mathrm{H} 4$ nilai VCL spermatozoa dalam pengencer tris aminomethane $(61,5 \mu \mathrm{m} / \mathrm{s} ; 54,4 \mu \mathrm{m} / \mathrm{s}$; $52,0 \mu \mathrm{m} / \mathrm{s}$ ) lebih tinggi secara nyata $(\mathrm{P}<0,05)$ daripada pengencer CEP-2 $(48,2 \mu \mathrm{m} / \mathrm{s} ; 40,4 \mu \mathrm{m} / \mathrm{s} ; 38,8 \mu \mathrm{m} / \mathrm{s})$ dan susu skim $(41,9 \mu \mathrm{m} / \mathrm{s} ; 3,8 \mu \mathrm{m} / \mathrm{s} ; 35,3$ $\mu \mathrm{m} / \mathrm{s})$. Nilai VCL spermatozoa dalam pengencer tris aminomethane lebih tinggi dari pengencer lainnya, menunjukkan bahwa vigor gerakan spermatozoa yang lebih kuat. Selama simpan dingin penurunan nilai VCL tertinggi pada pengencer susu skim, diikuti oleh CEP-2 dan tris aminomethane. Definisi dari VCL adalah kecepatan spermatozoa pada lintasannya yang dinyatakan dalam satuan $\mu \mathrm{m} / \mathrm{s}$. Nilai parameter ini hanya menunjukkan kekuatan pergerakan spermatozoa, namun tidak memberikan informasi tentang progresivitas spermatozoa maupun arah gerak spermatozoa (Perreault, 2002).

Nilai VCL semen cair sapi Madura selama masa simpan menunjukkan perbedaan yang nyata 
$(\mathrm{P}<0,05)$ antar pengencer pada $\mathrm{H} 0$ H4.Pada H0 nilai VCL dalam pengencer CEP-2 lebih tinggi $(59,6 \mu \mathrm{m} / \mathrm{s})$ secara nyata $(\mathrm{P}<0,05)$ daripada susu skim $(46,1$ $\mu \mathrm{m} / \mathrm{s}$ ) dan tidak berbeda nyata dengan tris aminomethane $(53,3 \mu \mathrm{m} / \mathrm{s})$. Pada $\mathrm{H} 1$ nilai VCL dalam pengencer tris aminomethane yang lebih tinggi (60,5 $\mu \mathrm{m} / \mathrm{s})$ secara nyata $(\mathrm{P}<0,05)$ daripada CEP-2 $(52,3 \mu \mathrm{m} / \mathrm{s})$ dan susu skim $(43,3$ $\mu \mathrm{m} / \mathrm{s}$ ). Pada $\mathrm{H} 2-\mathrm{H} 4$ nilai VCL spermatozoa dalam pengencer tris aminomethane $(61,5 \mu \mathrm{m} / \mathrm{s} ; 54,4 \mu \mathrm{m} / \mathrm{s}$; $52,0 \mu \mathrm{m} / \mathrm{s}$ ) lebih tinggi secara nyata $(\mathrm{P}<0,05)$ daripada pengencer CEP-2 $(48,2 \mu \mathrm{m} / \mathrm{s} ; 40,4 \mu \mathrm{m} / \mathrm{s} ; 38,8 \mu \mathrm{m} / \mathrm{s})$ dan susu skim $(41,9 \mu \mathrm{m} / \mathrm{s} ; 3,8 \mu \mathrm{m} / \mathrm{s} ; 35,3$ $\mu \mathrm{m} / \mathrm{s})$. Nilai VCL spermatozoa dalam pengencer tris aminomethane lebih tinggi dari pengencer lainnya, menunjukkan bahwa vigor gerakan spermatozoa yang lebih kuat. Selama simpan dingin penurunan nilai VCL tertinggi pada pengencer susu skim, diikuti oleh CEP-2 dan tris aminomethane. Definisi dari VCL adalah kecepatan spermatozoa pada lintasannya yang dinyatakan dalam satuan $\mu \mathrm{m} / \mathrm{s}$. Nilai parameter ini hanya menunjukkan kekuatan pergerakan spermatozoa, namun tidak memberikan informasi tentang progresivitas spermatozoa maupun arah gerak spermatozoa (Perreault, 2002).

Nilai VSL secara umun tidak menunjukkan perbedaan nyata selama penyimpanan dingin. Namun pada H1 nilai VSL spermatozoa dalam pengencer CEP-2 secara nyata $(\mathrm{P}<0,05)$ lebih tinggi daripada pengencer susu skim $(20,2 \mu \mathrm{m} / \mathrm{s})$ namun tidak berbeda nyata $(\mathrm{P}>0,05)$ dengan tris aminomethane $(22,8 \mu \mathrm{m} / \mathrm{s})$. Definisi VSL adalah kecepatan pergerakan spermatozoa dalam satu jalur/arah lurus yang dinyatakan dalam satuan $\mu \mathrm{m} / \mathrm{s}$. Selama penyimpanan terjadi penurunan nilai VSL secara bertahap. Parameter ini menunjukkan progresivitas gerakan spermatozoa, namun tidak menunjukkan pola gerakan spermatozoa (Perreault, 2002). Nilai rataan VSL dalam pengencer CEP-2 lebih tinggi daripada tris aminomethane dan susu skim, walaupun secara statistik tidak berbeda nyata selama penyimpanan. Hal ini mengindikasikan spermatozoa dalam pengencer CEP-2 lebih progresif daripada spermatozoa dalam pengencer tris aminomethane dan susu skim.

Nilai VAP spermatozoa pada $\mathrm{H} 0-\mathrm{H} 2$ menunjukkan perbedaan nyata $(\mathrm{P}<0,05)$ antar pengencer. Pada $\mathrm{H} 0$, VAP dalam pengencer CEP-2 lebih tinggi $(41,7 \mu \mathrm{m} / \mathrm{s})$ secara nyata $(\mathrm{P}<0,05)$ daripada susu skim $(34,0 \mu \mathrm{m} / \mathrm{s})$, namun tidak berbeda nyata $(\mathrm{P}>0,05)$ dengan tris aminomethane $(36,4 \mu \mathrm{m} / \mathrm{s})$. Pada H1, VAP spermatozoa dalam pengencer tris aminomethane $(32,6 \mu \mathrm{m} / \mathrm{s})$ dan CEP-2 $(33,1 \mu \mathrm{m} / \mathrm{s})$ secara nyata $(\mathrm{P}<0,05)$ lebih tinggi darpada susu skim $(25,5 \mu \mathrm{m} / \mathrm{s})$. Pada $\mathrm{H} 2$, nilai VAP dalam pengencer tris aminomethane (32,7 $\mu \mathrm{m} / \mathrm{s})$ secara nyata $(\mathrm{P}<0,05)$ lebih tinggi daripada susu skim $(26,0 \mu \mathrm{m} / \mathrm{s})$, namun tidak berbeda nyata dengan pengencer CEP-2 $(31,4 \mu \mathrm{m} / \mathrm{s})$. Secara keseluruhan, selama penyimpanan dingin terdapat penurunan nilai VAP secara bertahap. Hal ini berbeda dengan hasil penelitian Tardif et al., (1997) yang menyatakan bahwa nilai VAP akan naik setelah pengenceran dan kemudian turun secara bertahap selama penyimpanan. Definisi dari VAP adalah kecepatan rata-rata spermatozoa, yang dihitung dengan membagi panjang alur dengan waktu tempuhnya yang dinyatakan dalam satuan $\mu \mathrm{m} / \mathrm{s}$.

Salah satu faktor yang mempengaruhi kecepatan spermatozoa adalah media (pengencer). Sebagaimana disampaikan sebelumnya bahwa pengencer tris aminomethane dan CEP2 mempunyai konsistensi yang lebih 
encer daripada susu skim sehingga mendukung kecepatan pergerakan (motilitas) spermatozoa lebih leluasa. Komposisi dalam pengencer tris aminomethan dan CEP-2 lebih lengkap dengan fungsi tersendiri dalam mendukung kehidupan spermatozoa sehingga mendukung kecepatan gerak spermatozoa. Walaupun sebagian besar kecepatan spermatozoa (VCL, VSL,
VAP), namun nilai rataan parameter kecepatan dalam pengencer susu skim lebih rendah daripada pengencer lainnya.

\section{LIN, STR, WOB}

Hasil observasi nilai LIN, STR dan WOB pada semen cair sapi Madura selama kegiatan penelitian berlangsung tertera pada Tabel 5.

Tabel 5. LIN, STR dan WOB spermatozoa semen cair Sapi Madura selama simpan dingin.

\begin{tabular}{|c|c|c|c|c|c|c|c|c|c|c|}
\hline \multirow{3}{*}{$\begin{array}{l}\text { Parameter } \\
\text { LIN (\%) }\end{array}$} & \multirow{3}{*}{$\begin{array}{c}\text { Hari } \\
\text { ke- } \\
(\mathrm{H})\end{array}$} & \multicolumn{9}{|c|}{ Pengencer } \\
\hline & & \multicolumn{3}{|c|}{$\begin{array}{c}\text { Tris } \\
\text { Aminomethane }\end{array}$} & \multicolumn{3}{|c|}{ CEP-2 } & \multicolumn{3}{|c|}{ Susu skim } \\
\hline & & 56,7 & \pm & 5,6 & 54,3 & \pm & 8,0 & 58,4 & \pm & 11,3 \\
\hline & 1 & 37,8 & \pm & $5,5^{\mathrm{b}}$ & 51,7 & \pm & $5,6^{\mathrm{a}}$ & 44,1 & \pm & $10,0^{\mathrm{ab}}$ \\
\hline & 2 & 35,7 & \pm & $7,9^{\mathrm{b}}$ & 52,7 & \pm & $5,8^{\mathrm{a}}$ & 48,1 & \pm & $10,0^{\mathrm{a}}$ \\
\hline & 3 & 33,4 & \pm & $4,5^{b}$ & 55,9 & \pm & $5,8^{\mathrm{a}}$ & 47,3 & \pm & $10,6^{\mathrm{a}}$ \\
\hline & 4 & 33,7 & \pm & $4,5^{\mathrm{b}}$ & 53,9 & \pm & $4,6^{\mathrm{a}}$ & 42,6 & \pm & $12,3^{\mathrm{a}}$ \\
\hline & 5 & 32,9 & \pm & $5,4^{\mathrm{b}}$ & 51,4 & \pm & $6,0^{\mathrm{a}}$ & 53,0 & \pm & $2,8^{\mathrm{a}}$ \\
\hline \multirow[t]{6}{*}{ STR (\%) } & 0 & 82,7 & \pm & 4,2 & 77,5 & \pm & 8,7 & 82,6 & \pm & 4,6 \\
\hline & 1 & 70,6 & \pm & $7,8^{\mathrm{b}}$ & 81,8 & \pm & $5,0^{\mathrm{a}}$ & 78,3 & \pm & $7,6^{\mathrm{ab}}$ \\
\hline & 2 & 66,3 & \pm & $9,3^{\mathrm{b}}$ & 81,5 & \pm & $5,9^{\mathrm{a}}$ & 79,2 & \pm & $4,6^{\mathrm{a}}$ \\
\hline & 3 & 63,5 & \pm & $5,1^{\mathrm{b}}$ & 84,6 & \pm & $3,3^{\mathrm{a}}$ & 80,9 & \pm & $3,4^{\mathrm{a}}$ \\
\hline & 4 & 65,5 & \pm & $6,5^{\mathrm{b}}$ & 84,3 & \pm & $1,5^{\mathrm{a}}$ & 79,3 & \pm & $3,6^{\mathrm{a}}$ \\
\hline & 5 & 64,7 & \pm & $6,7^{\mathrm{b}}$ & 78,7 & \pm & $2,6^{\mathrm{a}}$ & 80,2 & \pm & $2,8^{a}$ \\
\hline \multirow[t]{6}{*}{ WOB (\%) } & 0 & 68,4 & \pm & 3,5 & 69,9 & \pm & 3,7 & 73,6 & \pm & 4,7 \\
\hline & 1 & 53,5 & \pm & $4,7^{\mathrm{b}}$ & 63,1 & \pm & $4,4^{\mathrm{a}}$ & 58,7 & \pm & $5,9^{\mathrm{a}}$ \\
\hline & 2 & 53,6 & \pm & $5,8^{b}$ & 64,5 & \pm & $4,4^{\mathrm{a}}$ & 62,6 & \pm & $5,2^{\mathrm{a}}$ \\
\hline & 3 & 52,4 & \pm & $4,4^{b}$ & 66,0 & \pm & $4,7^{\mathrm{a}}$ & 63,0 & \pm & $2,5^{\mathrm{a}}$ \\
\hline & 4 & 51,4 & \pm & $4,0^{\mathrm{b}}$ & 63,8 & \pm & $4,7^{\mathrm{a}}$ & 60,4 & \pm & $5,1^{\mathrm{a}}$ \\
\hline & 5 & 50,8 & \pm & $5,6^{\mathrm{b}}$ & 65,2 & \pm & $6,8^{\mathrm{a}}$ & 66,1 & \pm & $2,8^{\mathrm{a}}$ \\
\hline
\end{tabular}

Keterangan: superskrip yang berbeda pada baris yang sama menunjukkan perbedaan yang signifikan $(\mathrm{P}<0,05)$.

Berdasarkan Tabel 5 diketahui bahwa hampir semua parameter (LIN, STR dan WOB) menunjukkan perbedaan nyata $(\mathrm{P}<0,05)$ antar pengencer selama masa simpan (H1-
H5) namun tidak menunjukkan perbedaan nyata $(\mathrm{P}>0,05)$ pada $\mathrm{H} 0$. Nilai LIN pada $\mathrm{H} 1$ dengan pengencer CEP-2 lebih tinggi $(51,7 \%)$ secara nyata $(\mathrm{P}<0,05)$ daripada tris aminomethane $(37,8 \%)$, namun tidak berbeda nyata 
( $\mathrm{P}>0,05)$ dengan susu skim $(44,1 \%)$. Sedangkan pada $\mathrm{H} 2-\mathrm{H} 5$, nilai LIN pada pengencer CEP-2 (52,7\%; 55,9\%; $53,9 \% ; 51,4 \%)$ dan susu skim $(48,1 \%$; $47,3 \% ; 42,6 \% ; 53,0 \%)$ lebih tinggi secara nyata $(\mathrm{P}<0,05)$ daripada tris aminomethane $(35,7 \% ; 33,4 \% ; 33,7 \%$; $32,9 \%)$. Udrayana (2009) menyatakan LIN merupakan kelurusan lintasan curvelinear. Nilai LIN didapatkan dengan membagi VSL dengan VCL dikalikan dengan 100 dan dinyatakan dalam \%.Nilai STR pada H1 spermatozoa dalam pengencer CEP-2 $(81,8 \%)$ lebih tinggi secara nyata $(\mathrm{P}<0,05)$ daripada tris aminomethane (70,6\%), namun tidak berbeda nyata ( $\mathrm{P}>0,05)$ dengan susu skim $(78,3 \%)$. Sedangkan pada $\mathrm{H} 2-\mathrm{H} 5$, nilai STR spermatozoa dalam pengencer CEP-2 $(81,5 \% ; 84,6 \% ; 84,3 \% ; 78,7 \%)$ dan susu skim (79,2 \%; 80,9\%; 79,3\%; $80,2 \%$ ) secara nyata lebih tinggi daripada tris aminomethane $(66,3 \%$; $63,5 \% ; 65,5 \% ; 64,7 \%)$. Nilai STR didapatkan dengan membagi VSL dengan VAP dikalikan dengan 100 dan dinyatakan dalam \%. STR merupakan kelurusan rata-rata jalur spatial.

Nilai WOB selama simpan dingin (H1-H5) menunjukkan perbedaan yang nyata $(\mathrm{P}<0,05)$ antar pengencer yang digunakan. WOB dalam pengencer CEP-2 (63,1\%; $64,5 \% ; 66,0 \% ; 63,8 \% ; 65,2 \%)$ dan susu skim $(58,7 \% ; 62,6 \% ; 63,0 \% ; 60,4 \%$; $66,1 \%)$ secara nyata $(\mathrm{P}<0,05)$ lebih tinggi daripada tris aminomethane $(53,5 \% ; 53,6 \% ; 52,4 \% ; 51,4 \% ; 50,8 \%)$. Nilai WOB didapatkan dengan membagi VAP dengan VCL dikalikan 100 dan disajikan dalam \%. Pola renang spermatozoa ditentukan oleh nilai LIN dan STR spermatozoa. Udrayana (2009) menyatakan bahwa WOB merupakan pengukuran osilasi lintasan sebenarnya.

\section{Hiperaktif}

Status hiperaktif spermatozoa dalam semen cair sapi Madura menggunakan tiga pengencer berbeda selama simpan dingin tertera pada Tabel 6.

Tabel 6. Hiperaktif spermatozoa semen cair Sapi Madura selama simpan dingin.

\begin{tabular}{|c|c|c|c|c|c|c|c|c|c|c|}
\hline \multirow{2}{*}{ Parameter } & \multirow{2}{*}{$\begin{array}{c}\text { Hari } \\
\text { ke- }(\mathrm{H})\end{array}$} & \multicolumn{9}{|c|}{ Pengencer } \\
\hline & & \multicolumn{3}{|c|}{ Tris Aminomethane } & \multicolumn{3}{|c|}{ CEP-2 } & \multicolumn{3}{|c|}{ Susu skim } \\
\hline \multirow{6}{*}{$\begin{array}{l}\text { Hiperaktif } \\
(\%)\end{array}$} & 0 & 9,5 & \pm & 4,8 & 7,8 & \pm & 1,0 & 5,6 & \pm & 2,0 \\
\hline & 1 & 15,5 & \pm & 11,0 & 9,9 & \pm & 7,8 & 10,0 & \pm & 6,1 \\
\hline & 2 & 13,0 & \pm & 4,2 & 9,6 & \pm & 5,3 & 12,2 & \pm & 8,2 \\
\hline & 3 & 7,7 & \pm & 3,9 & 6,3 & \pm & 5,6 & 6,5 & \pm & 6,2 \\
\hline & 4 & 9,1 & \pm & 5,7 & 3,5 & \pm & 1,6 & 4,6 & \pm & 3,7 \\
\hline & 5 & 6,4 & \pm & 2,5 & 2,0 & \pm & 1,1 & 6,7 & \pm & 2,3 \\
\hline
\end{tabular}

Keterangan: superskrip yang berbeda pada baris yang sama menunjukkan perbedaan yang signifikan $(\mathrm{P}<0.05)$.

Berdasarkan Tabel 6. diketahui bahwa nilai hiperaktif spermatozoa antar pengencer selama simpan dingin tidak menunjukkan perbedaan nyata $(\mathrm{P}>0,05)$. Rentang nilai hiperaktif antar pengencer cukup jauh karena data yang variatif sehingga secara statistik tidak menunjukkan perbedaan yang nyata. Namun dari nilai rataan, nilai hiperaktif pada pengencer tris aminomethane lebih tinggi daripada pengencer CEP-2 dan susu skim. 
Kriteria spermatozoa hiperaktif dengan menggunakan SCA v 5.2. adalah spermatozoa yang mempunyai nilai VCL $>150 \mu \mathrm{m} / \mathrm{s}$, LIN $<50 \%$ dan ALH $>5 \mu \mathrm{m}$. Selama penyimpanan, pengencer tris aminomethane cenderung menunjukkan nilai VCL yang lebih tinggi dan STR yang lebih rendah daripada pengencer CEP-2 dan susu skim. Sedangkan nilai ALH cenderung stabil selama simpan dingin. Schmidt and Kamp (2004) menyatakan kejadian hiperaktif merupakan indikasi terjadinya kapasitasi spermatozoa. Terjadi kenaikan arus $\mathrm{Ca}^{2+}$ dan memicu terjadinya reaksi akrosom. Hasil penelitian sebelumnya menunjukkan hasil yang sangat bervariasi dan tidak ada standar kriteria hasil analisa dengan
CASA. Hal ini terkait dengan banyak faktor yang mempengaruhi hasil analisa menggunakan CASA, diantaranya seting alat, preparasi sampel, keahlian analis dan sampel semen. Ripp et al. (2003) menyatakan batasan spermatozoa hiperaktif diantaranya: LIN $<60 \%, \quad$ ALH $>7,5 \mu \mathrm{m}$ dan $\mathrm{VCL}>100 \mu \mathrm{m} / \mathrm{s}$.

\section{ALH dan BCF}

Nilai ALH dan BCF dari hasil analisa menggunakan SCA versi 5.2. merupakan paramater yang menunjukkan pola gelombang spermatozoa. Hasil pengamatan nilai ALH dan BCF semen cair sapi Madura selama penyimpanan dingin tertera pada Tabel 7.

Tabel 7. ALH dan BCF spermatozoa semen cair Sapi Madura selama simpan dingin.

\begin{tabular}{|c|c|c|c|c|c|c|c|c|c|c|}
\hline \multirow{3}{*}{$\begin{array}{l}\text { Parameter } \\
\text { ALH }(\mu \mathrm{m})\end{array}$} & \multirow{3}{*}{$\begin{array}{c}\begin{array}{c}\text { Hari } \\
\text { ke- } \\
(\mathrm{H})\end{array} \\
0\end{array}$} & \multicolumn{9}{|c|}{ Pengencer } \\
\hline & & \multicolumn{3}{|c|}{$\begin{array}{c}\text { Tris } \\
\text { Aminomethane }\end{array}$} & \multicolumn{3}{|c|}{ CEP-2 } & \multicolumn{3}{|c|}{ Susu skim } \\
\hline & & 2,0 & \pm & $0,3^{\mathrm{a}}$ & 2,0 & \pm & $0,1^{\mathrm{a}}$ & 1,6 & \pm & $0,2^{\mathrm{b}}$ \\
\hline & 1 & 3,0 & \pm & $0,3^{\mathrm{a}}$ & 2,1 & \pm & $0,2^{b}$ & 2,2 & \pm & $0,2^{\mathrm{b}}$ \\
\hline & 2 & 2,9 & \pm & $0,5^{\mathrm{a}}$ & 2,1 & \pm & $0,2^{\mathrm{b}}$ & 2,1 & \pm & $0,3^{\mathrm{b}}$ \\
\hline & 3 & 2,8 & \pm & $0,2^{\mathrm{a}}$ & 1,9 & \pm & $0,2^{\mathrm{b}}$ & 2,0 & \pm & $0,1^{\mathrm{b}}$ \\
\hline & 4 & 2,9 & \pm & $0,2^{\mathrm{a}}$ & 1,8 & \pm & $0,1^{\mathrm{b}}$ & 2,0 & \pm & $0,2^{\mathrm{b}}$ \\
\hline & 5 & 2,8 & \pm & $0,5^{\mathrm{a}}$ & 1,7 & \pm & $0,1^{\mathrm{b}}$ & 1,8 & \pm & $0,1^{\mathrm{b}}$ \\
\hline \multirow[t]{6}{*}{$\mathrm{BCF}(\mathrm{Hz})$} & 0 & 12,6 & \pm & 0,7 & 13,0 & \pm & 0,8 & 12,1 & \pm & 0,6 \\
\hline & 1 & 9,9 & \pm & $2,4^{\mathrm{b}}$ & 12,6 & \pm & $1,1^{\mathrm{a}}$ & 11,1 & \pm & $1,4^{\mathrm{ab}}$ \\
\hline & 2 & 10,1 & \pm & $1,9^{b}$ & 11,8 & \pm & $1,5^{\mathrm{a}}$ & 11,2 & \pm & $0,8^{\mathrm{ab}}$ \\
\hline & 3 & 9,0 & \pm & $1,6^{\mathrm{b}}$ & 11,5 & \pm & $1,6^{\mathrm{a}}$ & 10,7 & \pm & $1,5^{\mathrm{ab}}$ \\
\hline & 4 & 8,5 & \pm & $1,7^{\mathrm{b}}$ & 12,1 & \pm & $1,6^{\mathrm{a}}$ & 10,3 & \pm & $0,9^{\mathrm{ab}}$ \\
\hline & 5 & 8,5 & \pm & $3,5^{\mathrm{b}}$ & 14,1 & \pm & $3,5^{\mathrm{a}}$ & 12,6 & \pm & $3,2^{\mathrm{ab}}$ \\
\hline
\end{tabular}

Keterangan: superskrip yang berbeda pada baris yang sama menunjukkan perbedaan yang signifikan $(\mathrm{P}<0,05)$.

Nilai ALH pada H0 menunjukkan perbedaan yang nyata $(\mathrm{P}<0,05)$ pada pengencer tris aminomethane $(2,0 \mu \mathrm{m})$ dan CEP-2 (2,0 $\mu \mathrm{m})$ lebih tinggi daripada susu skim $(1,6 \mu \mathrm{m})$. Sedangkan pada H1-H5 nilai
ALH pada pengencer tris aminomethane $(3,0 \mu \mathrm{m} ; 2,9 \mu \mathrm{m} ; 2,8 \mu \mathrm{m} ; 2,9 \mu \mathrm{m} ; 2,8$ $\mu \mathrm{m})$ secara nyata lebih tinggi daripada CEP-2 $(2,1 \mu \mathrm{m} ; 2,1 \mu \mathrm{m} ; 1,9 \mu \mathrm{m} ; 1,8$ $\mu \mathrm{m} ; 1,7 \mu \mathrm{m})$ dan susu skim $(2,2 \mu \mathrm{m} ; 2,1$ $\mu \mathrm{m} ; 2,0 \mu \mathrm{m} ; 2,0 \mu \mathrm{m} ; 1,8 \mu \mathrm{m})$. Nilai 
ALH didapatkan dari hitungan matematis dari jarak maksimum excursion dari jalur lintasan dan jarak maksimum dari rataan alur. Nilai ALH antar hasil penelitian berbeda tergantung dari banyak faktor diantaranya jenis CASA yang digunakan (Perreault, 2002), standar lintasan spermatozoa dan seting alatnya. Semua nilai rataan ALH spermatozoa dalam tiga pengencer selama simpan dingin relatif stabil dan masih berada di level $<5 \mu \mathrm{m}$. Hal ini berlawanan dengan hasil penelitian Tardif et al (1996) bahwa selama simpan dingin nilai ALH semen cair akan semakin meningkat yang ditandai dengan banyaknya gerakan kepala star-shaped pattern.

Nilai BCF pada $\mathrm{H} 0$ tidak terdapat perbedaan nyata $(\mathrm{P}>0,05)$ antar pengencer. Namun pada H1-H5, nilai BCF pada pengencer CEP-2 $(12,6 \mathrm{~Hz}$; $11,8 \mathrm{~Hz} ; 11,5 \mathrm{~Hz} ; 12,1 \mathrm{~Hz} ; 14,1 \mathrm{~Hz})$ secara nyata $(\mathrm{P}<0,05)$ lebih tinggi daripada tris aminomethane $(9,9 \mathrm{~Hz}$; $10,1 \mathrm{~Hz} ; 9,0 \mathrm{~Hz} ; 8,5 \mathrm{~Hz} ; 8,5 \mathrm{~Hz})$, namun tidak berbeda nyata $(\mathrm{P}>0,05)$ dengan susu skim $(11,1 \mathrm{~Hz} ; 11,2 \mathrm{~Hz}$; $10,7 \mathrm{~Hz} ; 10,3 \mathrm{~Hz} ; 12,6 \mathrm{~Hz})$. Beat cross frequency didefinisikan sebagai banyaknya lintasan spermatozoa melalui rata-rata alur per detik. Nilai $\mathrm{BCF}$ juga tergantung dari sistem CASA yang digunakan.

Nilai ALH pada H0 menunjukkan perbedaan yang nyata $(\mathrm{P}<0,05)$ pada pengencer tris aminomethane $(2,0 \mu \mathrm{m})$ dan CEP-2 $(2,0$ $\mu \mathrm{m})$ lebih tinggi daripada susu skim $(1,6 \mu \mathrm{m})$. Sedangkan pada H1-H5 nilai ALH pada pengencer tris aminomethane $(3,0 \mu \mathrm{m} ; 2,9 \mu \mathrm{m} ; 2,8 \mu \mathrm{m} ; 2,9 \mu \mathrm{m} ; 2,8$ $\mu \mathrm{m})$ secara nyata lebih tinggi daripada CEP-2 $(2,1 \mu \mathrm{m} ; 2,1 \mu \mathrm{m} ; 1,9 \mu \mathrm{m} ; 1,8$ $\mu \mathrm{m} ; 1,7 \mu \mathrm{m})$ dan susu skim $(2,2 \mu \mathrm{m} ; 2,1$ $\mu \mathrm{m} ; 2,0 \mu \mathrm{m} ; 2,0 \mu \mathrm{m} ; 1,8 \mu \mathrm{m})$. Nilai ALH didapatkan dari hitungan matematis dari jarak maksimum excursion dari jalur lintasan dan jarak maksimum dari rataan alur. Nilai ALH antar hasil penelitian berbeda tergantung dari banyak faktor diantaranya jenis CASA yang digunakan (Perreault, 2002), standar lintasan spermatozoa dan seting alatnya. Semua nilai rataan ALH spermatozoa dalam tiga pengencer selama simpan dingin relatif stabil dan masih berada di level $<5 \mu \mathrm{m}$. Hal ini berlawanan dengan hasil penelitian Tardif et al (1996) bahwa selama simpan dingin nilai ALH semen cair akan semakin meningkat yang ditandai dengan banyaknya gerakan kepala star-shaped pattern.

Nilai BCF pada $\mathrm{H} 0$ tidak terdapat perbedaan nyata $(\mathrm{P}>0,05)$ antar pengencer. Namun pada H1-H5, nilai BCF pada pengencer CEP-2 $(12,6 \mathrm{~Hz}$; $11,8 \mathrm{~Hz} ; 11,5 \mathrm{~Hz} ; 12,1 \mathrm{~Hz} ; 14,1 \mathrm{~Hz})$ secara nyata $(\mathrm{P}<0,05)$ lebih tinggi daripada tris aminomethane $(9,9 \mathrm{~Hz}$; 10,1 Hz; 9,0 Hz; 8,5 Hz; 8,5 Hz), namun tidak berbeda nyata $(\mathrm{P}>0,05)$ dengan susu skim $(11,1 \mathrm{~Hz} ; 11,2 \mathrm{~Hz}$; $10,7 \mathrm{~Hz} ; 10,3 \mathrm{~Hz} ; 12,6 \mathrm{~Hz})$. Beat cross frequency didefinisikan sebagai banyaknya lintasan spermatozoa melalui rata-rata alur per detik. Nilai $\mathrm{BCF}$ juga tergantung dari sistem CASA yang digunakan.

\section{KESIMPULAN}

Motilitas dan motilitas progresif spermatozoa pada pengencer tris aminomethane dan CEP-2 lebih tinggi daripada susu skim selama 5 hari penyimpanan dingin. Nilai VCL pada pengencer tris aminomethane lebih tinggi daripada CEP-2 dan susu skim. Nilai VSL hampir tidak menunjukkan perbedaan antar pengencer. Nilai VAP pada pengencer tris dan CEP-2 lebih tinggi daripada susu skim pada awal penyimpanan. Nilai LIN, STR dan WOB pada pengencer CEP-2 dan susu skim menghasilkan nilai yang lebih 
tinggi daripada tris aminomethane. Nilai persentasi hiperaktif spermatozoa sama antar pengencer. Nilai ALH pada pengencer tris aminomethane lebih tinggi daripada CEP-2 dan susu skim. Nilai BCF pada CEP-2 lebih tinggi daripada susu skim dan tris aminomethane. Pengencer tris aminomethane dan CEP-2 lebih mendukung kualitas motilitas spermatozoa semen cair sapi Madura selama 5 hari simpan dingin daripada susu skim.

\section{DAFTAR PUSTAKA}

Abavisani, A., Arshami, J., Naserian, A. A., Kandelousi, M. A. S and Azizzadeh, M. 2013. Quality of Bovine Chilled of FrozenThawed Semen After Addition of Omega-3 Fatty Acids Supplementation to Extender. Int. J Fertil Steril7 (3): 161-168.

Akhter, S., Ansari M.A., Rakha B.A., Andrabi S.M.H., Anwar M. and Ullah N. 2010.Effect of Fructose Addition in Skim Milk Extender on the Quality of Liquid NiliRavi Buffalo (Bubalus bubalis) Semen. Pakistan J. Zool. 42(3): 227-231.

Amann, R. P and Waberski, D. 2014. Computer-assisted sperm analysis (CASA): Capabilities and potential developments. Theriogenology81: 5-17.

Anonimous. 2016. SCA evolutionVeterinary edition. http://www.micropticsl.com/doc uments-and-support/scatutorial/. Diakses tanggal 16 September 2016.

Arifiantini, R.I., Purwantara, B., Yusuf, T.L. and Sajuthi, D. 2013. The Quality of Stallion Semen in Skim Milk and Dimitropoulos Extenders Preserved at $5^{\circ} \mathrm{C}$ and Ambient
Temperature Supplemented with Different Sugar. Media Peternakan: 45-51.

Ax R.L., Dally M.R., Didion B.A., Lenz R.W., Love C.C., Varner D.D., Hafez B. and Bellin M.E. 2008. Semen Evaluation. Reproductive in Farm Animals. 8th Edition. Edited by Hafez and Hafez.Lea and Febiger: 365-375.

Contri, A., Valorz, C., Faustini, M., Wegher, L and Carluccio, A. 2010. Effect of semen preparation on casa motility results in cryopreserved bull spermatozoa. Theriogenology 74: $\quad$ 424-435. www.theriojournal.com.

Didion, B.A. 2008. Computer-assisted semen analysis and its utility for profiling boar semen samples. Theriogenology 70:1374-1376.

Ducha, N., Susilawati, T. and Wahjuningsih, S. 2012. Ultrastructure and Fertilizing Ability of Limousin Bull Sperm after Storage in CEP-2 Extender with and Without Egg Yolk. Pakistan Jornal of Biological Sciences 15: 979-985.

Hafez, E.S.E. 2008. Preservation and Cryopreservation of Gametes and Embryos. Reproductive in Farm Animals $8^{\text {th }}$ Edition. Edited by Hafez and Hafez. Lea and Febiger. Philadelphia: 431-441.

Holt, W. V., O'Brien, J and Abaigar T. 2007. Applications and interpretation of computerassisted sperm analyses and sperm sorting methods in assisted breeding and comparative research. Reproduction, Fertility and Development 19: 709-718.

Indriani, Susilawati, T. dan Wahjuningsih, S. 2013. Daya Hidup Spermatozoa Sapi 
Limousin yang Dipreservasi dengan Metode Water Jacket dan Free Water Jacket. Jurnal Veteriner 14 (3): 379-386.

Kostaman, T. dan Sutama, I. K. 2006. Studi Motilitas dan Daya Hidup Spermatozoa Kambing Boer Pada Pengencer Tris-SitratFruktosa. J. Sain Veteriner 24 (1) : 58-63.

Kutsiyah, F . 2012. Analisis Pembibitan Sapi Potong di Pulau Madura. Wartazoa 22(3).

Lange-Consiglio, A., Meucci, A and Cremonesi, F. 2013. Fluorescent multiple staining and CASA system to access boar sperm viability and membranes integrity in short and long-term extenders. Open Veterinary Journal3 (1): 21-35.

Lukman H. Y., Busono, W., Wahjuningsih, S and Suyadi, S. 2014. Sperm Motility and Viability after $\alpha$-Tocopherol Dilution in Tris AminomethaneBase Extender During Cold Storage in Bali Bull. International Journal of Chem Tech Research6(14): 5726-5732.

Massanyi, P., Chrenek, P., Lukac, N., Makarevich, A. V., Ostro, A., Zivcak, J and Bulla, J. 2008. Comparison of Different Evaluation Chambers for Analysis of Rabbit Spermatozoa Motility Parameters Using CASA Syatem. Slovak J. Anim. Sci. 41 (2): 60-66.

Purwoistri, R.F., Susilawati, T. and Rahayu, S. 2013. Membran Spermatozoa Hasil Seksing Gradien Albumin Berpengencer Andromed dan Cauda Epididymal Plasma-2

Ditambahkan Kuning. Jurnal Veteriner 14 (3): 371-378.
Perreault, S. D. 2002. Smart Use of Computer-Aided Sperm Analysis (CASA) to Characterize Sperm Motion. Reproductive Toxicology Division. U.S. Environmental Protection Agency National Health And Environmental Effects Research Laboratory.

Sarastina, Susilawati, T dan Ciptadi, G. 2006. Analisa Beberapa Parameter Motilitas Spermatozoa Pada Berbagai Bangsa Sapi Menggunakan Computer Assisted Semen Analysis (CASA). J. Ternak Tropika 6 (2): 1-12.

Schmidt, H and Kamp, G. 2004. Induced hyperactivity in boar spermatozoa and its evaluation by computer-assisted sperm analysis. Reproduction 128: 171-179.

Simonik, O., Sichtar, J., Krejcarkova, A., Rajmon, R., Stadnik, L., Beran, J., Dolezalova, $\mathrm{M}$ and Biniova Z. 2015. Indian Journal of Animal Sciences 85 (1): 3-11.

Singh, S., Gupta, H. P., Misra, A. K and Kumar, A. 2011. In-Vitro Capacitation of Bovine Spermatozoa by Measuring Penetrating Potential. Indian Journal of Animal Reproduction 32 (1).

Susilawati, $\mathrm{T}$. 2011. Spermatology.Cetakan pertama.Universitas Brawijaya Press. Malang.

Tambing, S.N., Sutama, I.K. dan Sariubang, M. 2009. Efektivitas konsentrasi kuning telur di dalam pengencer tris dengan dan tanpa plasma semen terhadap kualitas semen beku kambing Saanen. JITV 13 (4): 315-322. 
Tardiff, A. L., Farrel, P. B., Trouerntrend and Foote, R. H. 1996. Computer-Assisted Sperm Analysis for Assesing Initial Semen Quality and Changes During Storage at $5^{\circ} \mathrm{C}$. J. Dairy Sci 80: 1606-1612.

Udrayana, S. B. 2009. Proteksi Spermatozoa kambing Peranakan Etawah Menggunakan Fosfatidilkolin Dalam Proses Sexing Pada Gradien BSA dan Pembekuan. Disertasi. Program Studi Doktor Ilmu Peternakan. Program Pascasarjana Fakultas Peternakan. Universitas Diponegoro Semarang.

Vishwanath, R. and Shannon, P. 2000. Storage of Bovine Semen in liquid and frozen state.Anim. Rep. Sci. 62: 23-53.

Widjaya N. 2011. Pengaruh Pemberian Susu Skim dengan Pengencer Tris Kuning Telur terhadap Daya Tahan Hidup Spermatozoa Sapi pada Suhu Penyimpanan $5^{\circ} \mathrm{C}$. Sains Peternakan Vol. 9 (2): 72-76.

Wiratri, V.D.B., Susilawati, T. dan Wahjuningsih, S. 2014. Kualitas Semen Sapi Limousin Pada Pengencer Yang Berbeda Selama Pendinginan. J. Ternak Tropika 15 (1):13-20 .

Yohana, T., Ducha, N. dan Rahardjo. 2014. Pengaruh Pengencer Sintetis dan Alami Terhadap Motilitas Spermatozoa Sapi Brahman Selama Penyimpanan dalam Suhu Dingin. Lentera Bio 3 (3): 261-265.

Zaenuri, L. A., Susilawati, T., Wahjuningsih, S., Sumitro, S. B. 2014. Preservation Effect of Crude Fig Fruit Filtrate (Ficus carica L) Added In to Tris Egg Yolk Based Extender on
Capacitating, Acrosome and Fertility of Half Blood Boer Buck Spermatozoa. IOSR Journal of Agriculture and Veterinary Science (IOSR-JAVS) 7 (5): 60-66. 